\title{
Explanation of Environmental Aesthetic Factors of Urban Design
}

\section{ALI REZA SADEGHI',MOHAMMAD REZA POURJAFAR ${ }^{2}$, ALI AKBAR TAGHVAEE ${ }^{3}$ and PARVIZ AZADFALLAH ${ }^{4}$}

${ }^{1} \mathrm{PhD}$ Candidate of Urban Design at Art and Architecture Faculty of Tarbiat Modares University, Tehran.
${ }^{2}$ Full Professor and Dean of the Department of Urban Design \& Planning,
Faculty of Art and Architecture at Tarbiat Modares University, Tehran.
${ }^{3}$ Associate Professor and Education Deputy Manager of Art and Architecture Faculty
at Tarbiat Modares University, Tehran.
${ }^{4}$ Associate Professor and Dean of the Department of Psychology,
Faculty of Humanitiesat Tarbiat Modares University, Tehran.

http://dx.doi.org/10.12944/CWE.9.2.35

(Received: July 12, 2014; Accepted: August 17, 2014)

\begin{abstract}
The main objective of this manuscript is to investigate the effects of environmental aesthetics elements of urban designing on formation of the main part of the city (as the fundamental characteristics of the urban form). For this purpose, this comparative article explains the environmental aesthetic elements that are affecting the formation of main structure of the cities during the history of urbanism history (Teotihuacan, Beijing, Athena, Rome, Paris, Washington, Brasilia, and Isfahan) to pave the way for analysis of environmental aesthetics and improvement of contemporary cities' quality. For this purpose, the present study employs analytical-descriptive research methods, and literature, references, and visual documents reviews. The results from this study indicate that environmental aesthetic elements of urban designing are affecting the formation of an urban form in two ways, namely visual-form and cognitive-semantic. Visual-form elements include the quality of landscape and its factors, the quality of urban buildings and their elements, the quality of public spaces and their elements, continuity, enclosure, diversity of forms, the quality of views and vistas, and coordination with the context. Cognitive-conceptual elements include identity, legibility, concept, perceptibility, coherent mental image, customizability, social and cultural environment, and richness of activities.
\end{abstract}

Key words: Environmental Aesthetics, Main Structure, Form of City, Visual-formal factors, Perceptional-meaning factors.

\section{INTRODUCTION}

There are two views on the concept of form. The first one looks at form versus content. Based on this old point of view, form or aspect is the shape and content is the performance of a phenomenon. On the other hand, according to the second perspective, form represents the aspect, structure, and the way content is developed, visualized, and expressed. From this standpoint, aesthetics is defined as emotional, obvious, and sensory presentation of a phenomenon which exposes itself to judgment.

Construction of a city or city's spatial structure shows the discipline and relationship between physical elements and uses and activities in the city. This structure is formed in the urban space and from the resultant of forces affecting the city over time. However, to such thinkers as Christopher Alexander and Edmond Bacon, construction of a city 
as a whole can be divided into core and non-core sectors. In effect, it is the major part that forms the vertebral column of the city and represents stability, continuity, identity, originality, and meaning of the city. In other words, this core structure is responsible for transferring the city's message to its citizens and visitors. Other parts of the city, which comprise the non-core part of it, are taken to be environments for showing diversity, freedom, authority, and change. At this time, it appears that if we consider the urban form as all elements of natural and human-made environment that surrounds human being, which men can potentially connect with it, the core structure of the city can be a fundamental characteristic of the urban form. Since, the main structure of the city is comprised of such elements as the key axes of communication, major open spaces, public buildings, etc., with which people are always connected. (Picture1)

On the other hand, environmental aesthetics is one of the two or three important areas of aesthetics which have been taken into consideration since the second half of twentieth century. The most significant subjects, with whom environmental aesthetics is involved, are those related to understanding of the universe aesthetics and world aesthetics whose constituents are not merely objects and phenomena. They are, rather, bigger elements found in the environment. Therefore, the domain of environmental aesthetics goes beyond the limited borders of the art world and human understanding and broadens to aesthetic understanding of natural and human-made artificial environments which are influenced by the presence of men. In this regard, it seems that in this era analysis of environmental aesthetics characteristics of urban form is more essential than ever. Since, today with expansion of cities, implementation of several projects in such human societies and ever increasing changes in form of the city and main structure of metropolises, the need for analysis and explanation of the effects from implementation of urban projects and plans on citizens and environment is sensed more than ever. Indeed, analysis of human-made environment and investigation of urban plans' impact on human being and environment are the main responsibilities of urban designers to meet high spectacular goals such as improvement of the quality of human-made environment.

\section{MATERIALS AND METHODS}

Through reviewing the previous researches in fields of form aesthetics and urban landscape in the past half century, it is evident that discussions about aesthetics in this field have gone through changes from a visual-artistic standpoint into an issue with perceptional-meaning tendencies. This is quite clear in the move from picturesque style to a conceptual tendency in the aesthetics of form and city landscape. picturesque which had an architectural focus on the artistic-visual aspects of landscape such as the plurality and diversity, humane scale, naturalism and organic order in form and color combination, has been popular by a group of scholars including Sitte, Gibberd, Halprin ${ }^{1,2}$. Despite modernists who advertise "object-like architecture", Collin takes "the art of communication" more into account, combines the Genius Loci (sense of place) with movement and brings about the constant views of the urban environment, ${ }^{3}$. On one hand, Collin's approach, however original and moving, is faced with criticism in the field of perception of beauty due to its focus on personal perception and feeling of an urban landscape experience. On the other hand, urban aesthetics do not have the capability to compete with Jacobs and Newman's approach which have been developed in the 60s and 70s in social-behavioral science ${ }^{4,5}$. In addition, it could not fit in with the phenomenological theories of Relph and Jakson ${ }^{6,7}$ or with theoretical and philosophical factors of Norberg Schulz in the following decade ${ }^{8}$

These new thought trends and considerations to different dimensions of urban design weakened discussions about aesthetics and particularly those related to picturesque and Collin's approach. Gradually, urban landscape aesthetics has moved its focus from a subjective, sentimental and professional attitude related to visual qualities such as form, color and context to a cognitive-perceptional study of urban landscape.For this reason, theories of form aesthetics and urban landscape are discussed more in psychological studies of the environment than in the field of urban design. Such theories include Appleton's survival theory in beauty preferences that seeks a relation between an appropriate condition for survival and beauty $^{9}$. In his evolutionary theory, Stephen Kaplan puts his focus on the obedience of people and the 
degree they are familiar with landscape, orientation, and obtaining new data in beauty preferences ${ }^{10}$.

Regarding what was said, explanation of environmental aesthetic elements of urban form and spaces seems essential. Therefore, the main objective of this text is to investigate the effects of environmental aesthetics elements of urban designing on formation of the main part of the city (as the fundamental characteristics of the urban form). Since, human is always interacting with surrounding environment and takes feeling, understanding, and intuition of its different aspects through his senses, especially sense of sight, into consideration. In fact, these feeling, understanding, and intuition of citizens of superficial aspects of the main structure form of the cities shape the ground for formation of coherent mental picture and good memory in them. In addition, with respect to urban design and environment quality improvement related issues, enhancement of objective and subjective aesthetic qualities (visual-form and conceptual-cognitive qualities) is very important in urban public realms, and it seems to have a fundamental role in form of legible and original cities.

This comparative article explains the environmental aesthetic elements that are affecting the formation of main structure of the cities during the history of urbanism history (Teotihuacan, Beijing, Athena, Rome, Paris, Washington, Brasilia, and Isfahan) to pave the way for analysis of environmental aesthetics and improvement of contemporary cities' quality. For this purpose, the present study employs analytical-descriptive research methods, and literature, references, and visual documents reviews.

\section{Environmental Aesthetics in Urban Design}

Theoreticiansof aesthetic theories are divided into three general groups including premodern era, modern and postmodern. The premodern period dates back to the times before the renaissance, i.e. the time when arts were serving the religion. (Those arts are also called traditional art). There was not much innovation and creativity in that period. Everything was reproduced in a traditional way and the artist did not have any opportunity to express his own imagination. Natural beauty (inspired by the nature) is prior to artistic and creative beauty ${ }^{11}$. The modern period emerges when tradition is expelled and everything is renewed. This renewing starts with the emergence of new territories and fields for human beings. Modern thought is actually rational thinking, self-centered and regards objective thinking, pragmatism, emotionalism and individual intuition and is, as a result, a kind of creativity and innovation which finally values the work's integrity and independence. When defining the modern aesthetics, we can refer to Frank Lloyd Wright and Le Corbusier who are two major modernist architects. Wright takes the concept of beauty in organic architecture from nature and believes that principles and order are the basic factorsfor an evolved beauty. Beauty is a proportional display as color, line and form. This proportion is so honest as if forms and colors seek their existential cause in displaying an eternal design. Here, it should be noted that it is not only the form and color that Wright considers as important in beauty; rather, he values the systematic nature, order, balance, and the hidden integrity of nature, and Le Corbusier as a pioneer of modern techniques utilizes forms which are products of modern engineering ${ }^{12}$. Quite the opposite, the postmodern era focuses on plurality, does not give any credit to the work's independent nature, takes non-artistic issues such as social-political status into account, and finally pulls the aesthetic value of a work of art to the edges.Postmodernbeauty is a plural beauty that is good for every "cultural taste" and for diverse impressions of a good life ${ }^{13}$. But, the present era in which capitalism is dominant in relations between human and his environment, aesthetic values are being neglected as a result of economic relations and also due to the necessity of a benefit-seeking attitude toward natural and artificial environment surrounding people. Therefore, to challenge this narrow-minded way of thinking toward the relation between human and his surrounding environment, new concepts are put forward in aesthetics which are in fact framed in an environmental aesthetics. Indeed, environmental aesthetic is a concept which should not be merely limited to contexts of place, ethics and spiritual thoughts, but rather, it should inevitably be implemented in a social, economical and political body.Environmental aesthetics is a multi-senseand widespread engagement with the environment of which human beings are the main components. In environmental aesthetics, when a sublime feeling reaches its peak, experience of beauty can be truly 


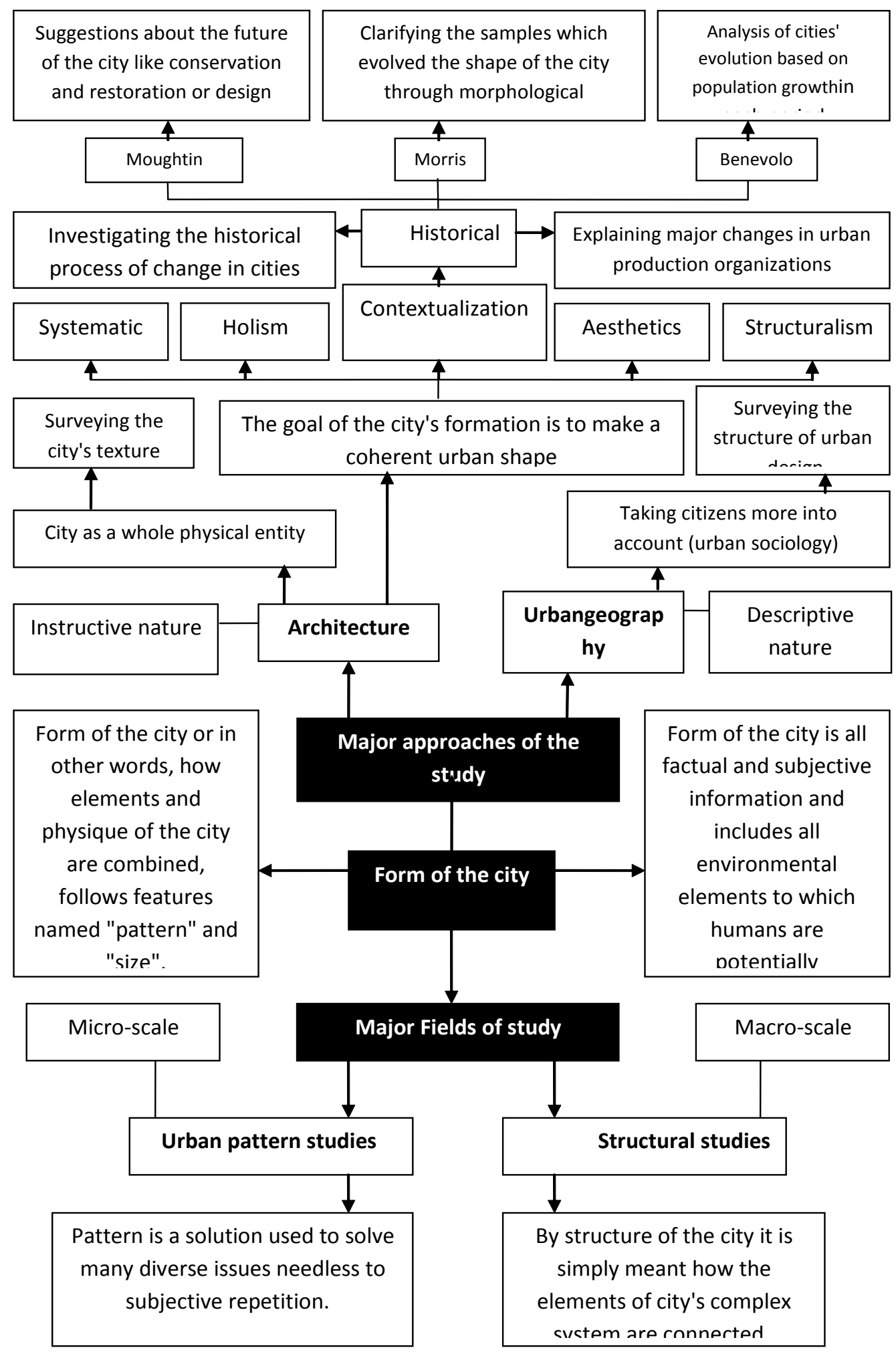

Picture1: approaches about city's form. Source: the authors using different sources 
strong and contain valuable mental stimulations. In this kind of aesthetics, beauty or the sublime can be a routine and typical pleasure, present in human being's surroundings the highest level of which is in an environment filled with integrity, complexity, and mystery. In Whitehead's aesthetic theory, it is stated that size or diversity of forms along with quality of intensity and comparative magnifying, needless to a variety of qualities, are able to generate a powerful environment. In fact, in environmental aesthetics, qualities of integrity, complexity and mystery are combined together in order to give meaning to the beauty and sublime in human's surrounding environment ${ }^{14}$. In respect to this, Schulz makes a connection between architecture, place and cultural identity and believes that experience of the place is actually the experience of the meaning of the place; and experience of beauty in an environment is indeed an appreciation of meaning ${ }^{8}$. In his book, "The Image of the City"', Lynch considers visualizing space and time as the basis to reach an understanding of environment, and thus, believes that all of these elements together have a close affinity with beauty ${ }^{15}$. In his normaltheory of the good

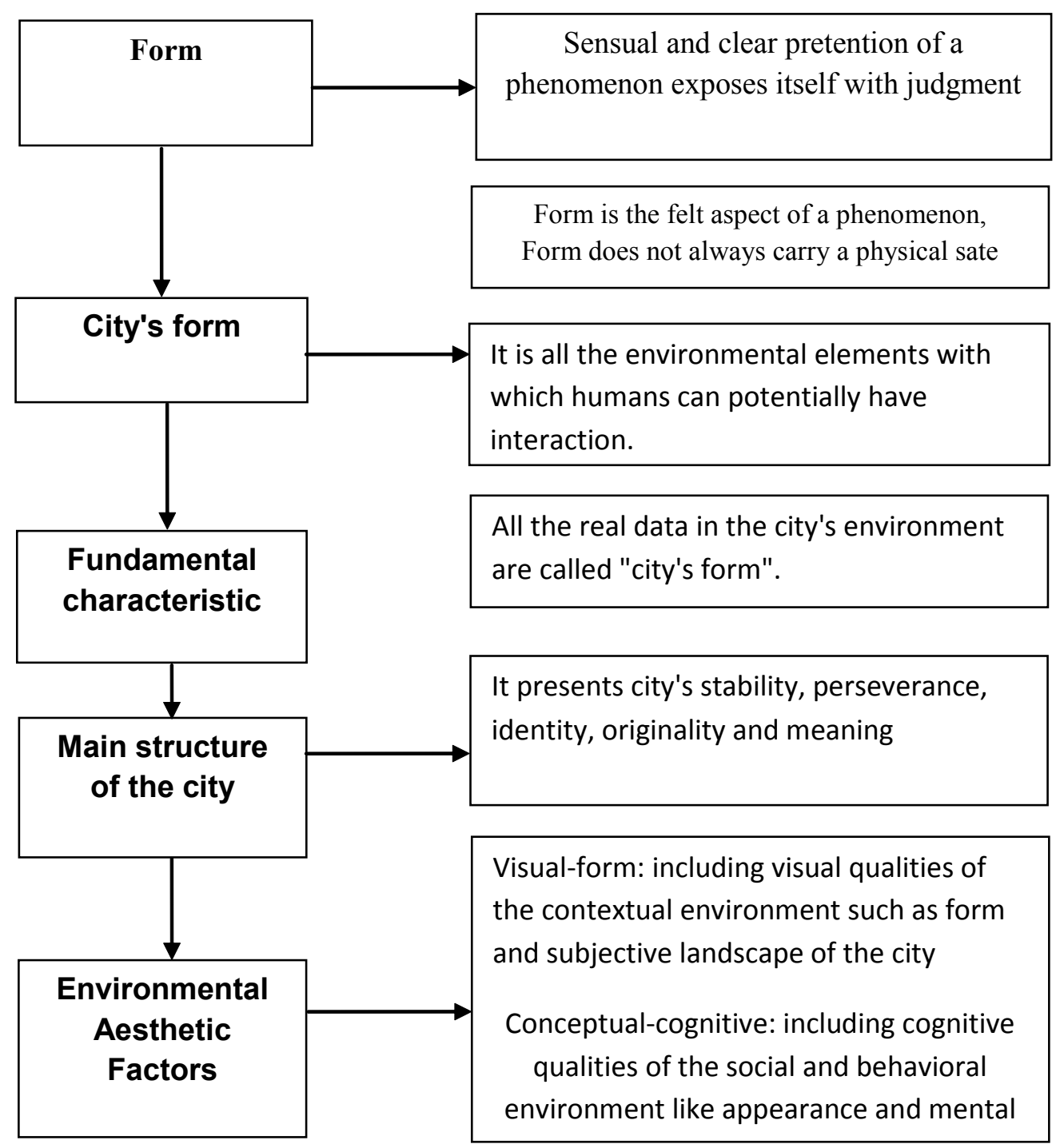

Picture 2: engagement of the city's form, main structure and environmental aesthetic factors; Source: the authors 
Table 1: Presentation of environmental aesthetic factors by urban design scholars. Sources: the authors using diverse sources

\begin{tabular}{|c|c|c|}
\hline \multirow[t]{2}{*}{ Theoretician } & \multicolumn{2}{|c|}{ Environmental Aesthetic Factors in Urban Design } \\
\hline & Visual-form factors & $\begin{array}{l}\text { Cognitive-conceptual } \\
\text { factors }\end{array}$ \\
\hline $\begin{array}{l}\text { Jane Jacobs } \\
(1961)\end{array}$ & Considering street elements & $\begin{array}{l}\text { Flexible spaces:The } \\
\text { possibility of socializing } \\
\text { Richness of activities }\end{array}$ \\
\hline $\begin{array}{l}\text { Kevin Lynch } \\
\text { (1984) }\end{array}$ & Compatibility and Fit & Sense, Vitality \\
\hline Violich (1983) & $\begin{array}{l}\text { Urban forms reminding of the past } \\
\text { (cultural heritage) }\end{array}$ & $\begin{array}{l}\text { legibility of the environment, } \\
\text { freedom of choice, } \\
\text { possibility of a social life }\end{array}$ \\
\hline $\begin{array}{l}\text { Ian Bentley and } \\
\text { Others (1985) }\end{array}$ & $\begin{array}{l}\text { Visual intrusion; diversity of forms; visual } \\
\text { compatibility }\end{array}$ & $\begin{array}{l}\text { legibility; flexibility; } \\
\text { customizability }\end{array}$ \\
\hline $\begin{array}{l}\text { Ragger Trancik } \\
\text { (1986) }\end{array}$ & $\begin{array}{l}\text { Enclosure of the spaces; fusion of edges; } \\
\text { controlling point of views and perspectives }\end{array}$ & $\begin{array}{l}\text { compatibility of interior } \\
\text { and exterior spaces }\end{array}$ \\
\hline Coleman (1987) & $\begin{array}{l}\text { Historical conservation and urban restoration; } \\
\text { architectural values }\end{array}$ & $\begin{array}{l}\text { Cultural environments, } \\
\text { delightfulness and variety } \\
\text { of Functions }\end{array}$ \\
\hline $\begin{array}{l}\text { Allen Jacobs and } \\
\text { Appleyard (1987) }\end{array}$ & Delightfulness (visual diversity) & $\begin{array}{l}\text { Originality and meaning; } \\
\text { collective life; identity and } \\
\text { dominance }\end{array}$ \\
\hline $\begin{array}{l}\text { Prince Charles } \\
(1989)\end{array}$ & $\begin{array}{l}\text { Hierarchy; scale; harmony; enclosure; materials; } \\
\text { decorations; art; symbols; signs and lights }\end{array}$ & $\begin{array}{l}\text { Position; local community; } \\
\text { (genius loci, sense of } \\
\text { place and belonging) }\end{array}$ \\
\hline $\begin{array}{l}\text { Michael } \\
\text { Soutworth (1989) }\end{array}$ & Structure; form; view and landscape & $\begin{array}{l}\text { Legibility; genius loci; } \\
\text { identity; human scale; } \\
\text { (passerby) }\end{array}$ \\
\hline $\begin{array}{l}\text { Francis } \\
\text { Tibbalds(1988- } \\
92)\end{array}$ & $\begin{array}{l}\text { Learning from the past; respecting the present } \\
\text { texture }\end{array}$ & $\begin{array}{l}\text { Considering places before } \\
\text { buildings; human scale; } \\
\text { legibility }\end{array}$ \\
\hline Greene (1992) & $\begin{array}{l}\text { Order includes: coherence, clarity, continuation. } \\
\text { Appeal includes: scale; visual coordination; harmony }\end{array}$ & $\begin{array}{l}\text { Identity includes: centre; } \\
\text { unity; character; } \\
\text { delightfulness }\end{array}$ \\
\hline $\begin{array}{l}\text { Brian Goodey } \\
(1993)\end{array}$ & Coordination with the current context; diversity & $\begin{array}{l}\text { Delightfulness; human } \\
\text { scale; customizability; } \\
\text { legibility; richness of } \\
\text { activities }\end{array}$ \\
\hline LPAC, (1993) & Intensity of texture; visual richness & $\begin{array}{l}\text { Structure, legibility and } \\
\text { identity, human scale, } \\
\text { public and specific places }\end{array}$ \\
\hline $\begin{array}{l}\text { Haughton and } \\
\text { Hunter (1994) }\end{array}$ & $\begin{array}{l}\text { Diversity; concentration, proper scale, creative co- } \\
\text { relations }\end{array}$ & 一- \\
\hline Nelessen, & The core(concentration center); street landscape; & Human scale \\
\hline
\end{tabular}


(1994)

PMUDTF

(1996)

Punter and

Carmona

(1997)

Richard Rogers

(1999)

Department of

environment,

transportation and

regions in Britain

(2000)

Summary diversity; use of design terminology

Considering the context and local character;

beholding capability

Objective urban landscape; artificial form; ground landscape

Character; considering sights and positions; context; scale

Character, continuity and enclosure, structure of urban space, urban divisions, i.e., street decoration patterns ;( blocks, pieces, and buildings); natural landscape; scale: altitude; scale: building; exterior: details; exterior: materials The quality of natural landscape and its factors, the quality of urban buildings and their elements, the quality of public spaces and their elements, continuity, enclosure, diversity of forms, the quality of views and vistas and coordination with the context
Public perception; quality evaluation; functions and perceived appeals; reminder of cultural concepts; legibility

Identity; legibility

Identity, legibility, concept, perceptibility, coherent mental image, customizability, cultural and social environment, richness of activities

Table 2: Explanation of the role of aesthetic - form factors in the main structure of cities. Source: the authors

\section{How environmental aesthetics has effected these cities}

Structure of this city: it was a center for magnificent feasts; there were pyramids called the Sun and the Moon pyramids which were used as an axis (place) to worship gods and it also had a main rout called "Road for the Dead" and other diverse elements located around it.

Positioning of all huge buildings in a vertical (upright) network Its base is on a pivot which has a specific geographical direction based on religious beliefs.

its general structure is not symmetrical

Positioning of minor pyramids' shafts is proportionate in relation to minor axis and disproportionate in relation to the "Road for the Dead" or the major axis.

The city is indeed a series of square-like modules.

It is influenced by two powerful axis, namely, the

king's seat and the Sun pyramid.

Dominant characteristic: diversity of combinations which are creatively free from the dominance of symmetrical pivots.

It is like branches of a tree and has an organic growth (organized growth).

There is a possibility of pursuing harmonious functions

with the whole system.
Teotihuacan, capital city of a civilization under the same name in central America, (first century A.D) 
Base of the work is on continuity and hierarchy

The focus is on the orientation of the main structure along with adding to the floors of the building

Clarifying direction of the movement of the main axis with the building, kind of the movement in pavements and gaining a chain of space experiences Moving in the space and passing from the spaces with different colors Passing from one scale into another

Presence of a specific rhythm of basic units from open and close spaces to the emperor's seat in the main axis.

Presence of an extensive pivot and several supporting units in the fringe Presence of a strong pivotal balance and lack of a stiff pivotal symmetry Structure of the city and its main elements surround Acropolis, Agora, some entertainment and cultural spot, a religious area and at times an industrial port Agora is the beating heart of the city and a place to practice different activities Formation of Agora in a place that was a market and meeting spot before and was located on the path of Panathenaic road or the main commuting road. Agora was in the physical center of the city between city's gate and Acropolis Around Agora, there were pavements, porches, and aprons for holding meetings and court sessions.

Pattern of organizing the main structure includes two major center and several marginal (minor) ones.

The link between the two major centers, that is, Agora and Acropolis, is done through a strong communication path

The most important element of the city, namely, acropolis and particularly Parthenon temple, has a great visual dominance over the whole city and the meeting center and that is due to its location on the highest part of the city. Every building complex has an internal order with the new ones around one pivot which has only one center.

There is a link between surrounded spaces, and a mutual adherence among the buildings There is an eternal beauty and diversity resulting from a link between spaces and the internal order of buildings.

A city beside the Tiber river and surrounding the Seven Hills

Rome, the Capital of Roman Emperors

The river and the Seven Hills had a great impact on space order of the structure of the city There were sanctuaries and shrines, graveyards and necks (causeway), public bathrooms, stadiums, theaters and special places for meetings, markets, gardens, and also squares in central part of the city. Forums or the city's meeting place and traditional markets are located in a valley among the hills and have the view of Jupiter temple which had been considered another important element of the city The city center's growth through a series of royal forums connected to each other and in a row ( the axis) are linked and the forums are connected to the new ones.

The main idea of the designers of the city monuments was to display their magnificence and splendor and their form in order to be dominant over all buildings of the city( Rome in the first century) Apart from the river and the Seven Hills, The main structure of 
ancient Rome around 3 A.D. consisted of isolated monumental

buildings in the central areas of the city.

There were a plethora of public buildings in the adjacent and connected complexes and all have orderly geometrical forms.

The main idea of the city's organization in Middle Ages was to make points or centers in the space which were defined by vertical elements and communication lines between them.

The central spots include intersections among the appealing forces (i.e. place of ancient buildings, churches, gates, and public squares). Endless diversity of angel communication spots and a vast variety of marginal places having different angles in relation to each other. When the structure was reorganized by Sixtus $V$ and influenced by baroque urbanization, places were designed to characterize some elements in the formless shape of buildings.

Some pivots and places were designed to define, explain and clarify the connection between sings of the old city.

In times of Sixtus V, in order to make communication possible among the main parts of the city, some parts were built in a lower level in order to have a greater view of the monuments.

The main structure of the city consists of two major axes, that is, east-west and north-east axis intersection of which is actually making the central part of the city.

The east-west axis is known as the main monumental axis and it is the ceremonial (formal) path. many outstanding buildings are formed on margins of the main axis In one side of the main axis, there is governmental triangle or square which has a view of a lake.

Location of the central churches, universities, trade centers and embassy buildings of the city are in a way which have cultural and entertainment centers in the margins of the two main axis of the city Building a monumental place in the entertainment spot of the beach between the congress building and TV tower through a pathway of shortcuts.

Presentation of a new outlook toward the city as a whole structure.

Presence of visual and symbolic values of the elements not only in regard to architectural qualities or exterior structure of buildings, but also, in regard to their positioning and combination.

Remarkable buildings and monuments of the city are at times located on the main axis of the urban roads.

The axis owns a definite and specific beginning and ending point. The Victory Gate is located in the center of the branching pattern of main streets and is seen from 12 streets.

There can be seen a visual continuity, passage of time and history over this city which bring a kind of order to the buildings that belong to different historical periods.

Regarding the visual order of the elements, their combination with marginal axis is performed in a way in which all significant elements are seen from the major axis in Champs-Elysees avenue.

There is an appropriate symmetry between the qualities of signs in the city in relation to its size.

There are agreeable distances between buildings so 
that they can be beheld from the adjacent monuments.

Observing principles of aesthetics in order to add to visual impact of urban signs

Combination of buildings and urban signs with open urban spaces

Having appropriate gradient and hills in order to a

have a better display of buildings.

Having unique visual characteristics on walls of the main pathways which include buildings with designed exteriors. The essential focus of the designer is on making pleasant urban views and dominant perspectives.

Washington, the United States of America

Elements and main central areas are being under spotlight from different directions through main streets. Main streets determine the spotlights and access to main areas of the city

Making exterior yards, axes, and pavements for entertainment and designing signs.

Three monuments including the Capitol Building, the White House, and the Washington Monument, are the main elements which dominate the city regarding, legibility and visual image and are truly influencing the total image of the city.

Making a visual connection among the streets by through defining elements

Cyclic patterns are utilized and the elements are put in a way that are seen easily and thus make closed perspectives and add to the visual aspects of the city's signs.

Making strong connections among monumental buildings while providing enclosed and formed spaces for human activities.

A porch (private spot) was designed for buildings which gives them dominance over the surrounding environment based on the position of the building.

There is a kind of visual attachment in the whole city, particularly in the central core.

There are proportionate architecture and similar forms in buildings located in main streets.

There are series of buildings with same height and continuation and substantial shapeless spaces which have a height limit. Rows of planted trees in both sides of certain streets have made defined landscapes.

The city has topographical relation with street lines determining the position of the main axis and its main elements. Using natural geographical facilities of the place in designing main structure of the city.

Main axis are selected in a way that not only give pleasant views toward the river, but also are contributing to the topographical land issues of the city in the best way possible.

There are engineered spaces, all in order and substantial.

Isfahan, Iran

Presence of diverse spaces

Having major views and perspectives

There is a coordination with context 
Diversity of space enclosures

Focusing on main buildings in public spaces

Using natural elements such as trees and rivers to put the city in order.

Continuity and attachment of older textures to newer ones

Arrayed construction of exteriors using

special architecture and ornamentation

form of a city, he points at insufficiency of concepts such as harmony, diversity, and order present in an object or landscape and believes that one should begin with cognitive images and users' priorities and see the person and place as a whole ${ }^{16}$. Boyer also discusses the role of collective memories and semantic dimensions in achieving the pleasure of an environment and understanding of its beauty ${ }^{17}$

From the environmental aesthetics point of view, an urban space is a beautiful space in which aesthetic criteria are involved in its construction and that means urban designing is actually the very creation of a beautiful urban space. There are two schools of thought in understanding beauty. One takes perceptional elements in time of perception into account and the other discusses non-perceptional elements such as culture, scientific knowledge and patterns as the influential factor.

\section{Explanation of Environmental Aesthetics Factors in Urban Design}

As mentioned above, nowadays, considering environmental aesthetics, explanation of its factors and utilizing them in analyzing urban spaces is of great significance in urban design. Authors of this article believe that environmental aesthetic factors in urban design are divided into two groups that are, visual-form qualities and cognitive-semantic qualities (conceptual-cognitive qualities). Visual-form elements include visual qualities of the contextual environment such as form and subjective landscape of the city and conceptual-cognitive elements include cognitive qualities of the social and behavioral environment like image and mental landscape of the city.

Furthermore, many of urban design scholars who have explained the qualities of a good urban design through a normal approach, have focused on taking environmental aesthetic factors into consideration in urban design. In table 1, both visual-form and conceptual-cognitive qualities of environmental aesthetics discussed by some urban design scholars are presented.

\section{DISCUSSION AND CONCLUSION}

It has been said that the main structure of every city is a fundamental characteristic of the city's form which has a remarkable role in that city's stability, continuity, identity, originality and meaning. It has also been noticed that environmental aesthetic factors have always played a vital role in the formation of a city's structure. (Picture 2)

Moreover, in this research, analysis of aesthetic factors presented by urban design scholars has led to the division of suggested environmental aesthetics of city's form into two groups, namely, visual-form factors and cognitive-conceptual factors. These factors include:

1. Aesthetic-form factors including: the quality of natural landscape and its elements, the quality of urban buildings and their elements, the quality of public spaces and their elements, continuity, enclosure, diversity of forms, the quality of views and vistas and coordination with the context

2. Cognitive-conceptual factors including: identity, legibility, concept, perceptibility, coherent mental image, customizability, social and cultural environment, richness of activities.

Besides, despite having different patterns of city structure and belonging to diverse civilizations, most ancient cities' form in different parts of the world have some things in common, and thus, through examining them, we can find certain principles about their shaping, survival and restoration of the main structure of the city. However, it seems that one common reason of the survival and restoration of these cities is use of environmental aesthetic factors, namely, visual-form factors and cognitiveconceptual factors, in urban design and in organizing 


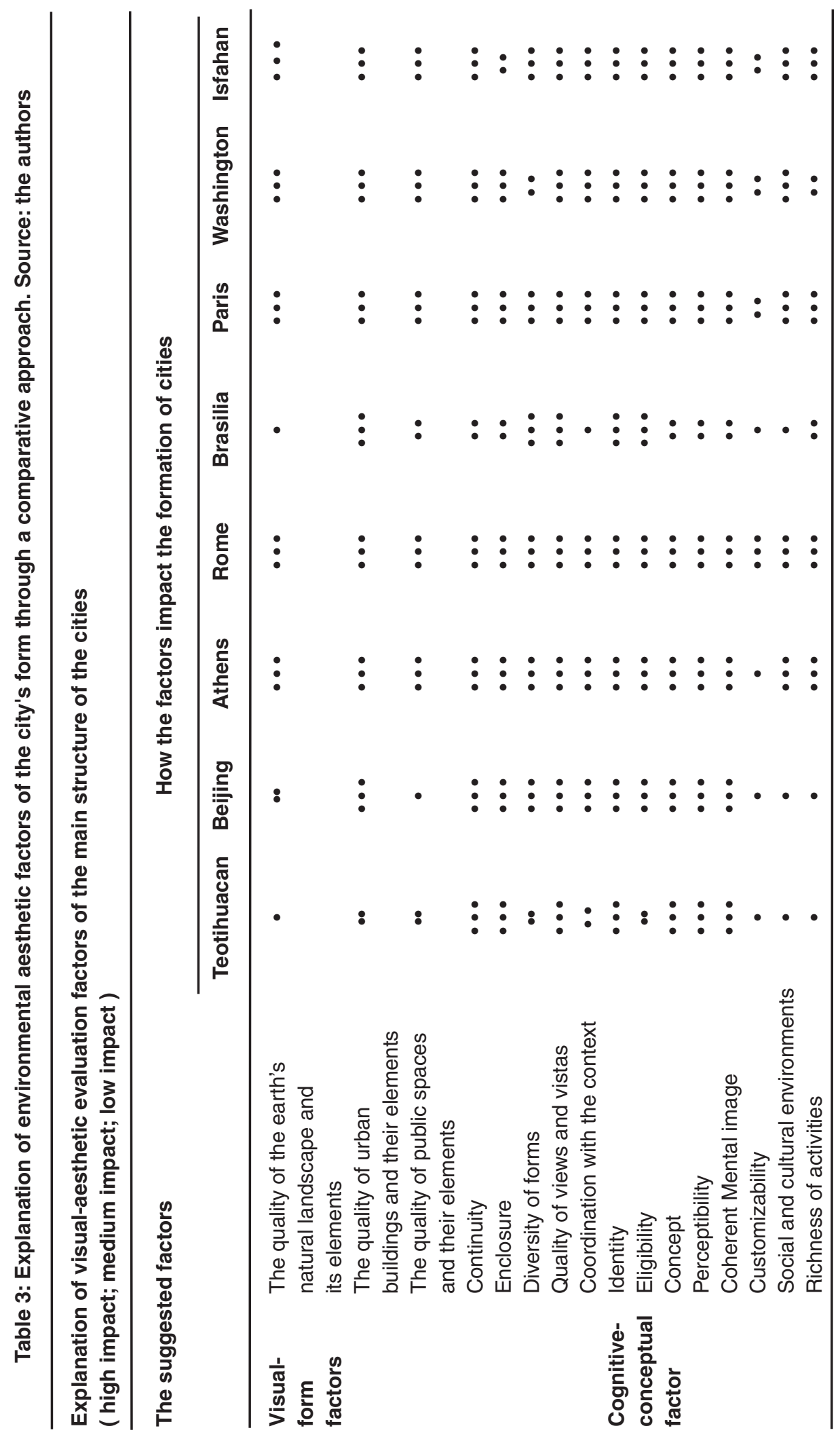




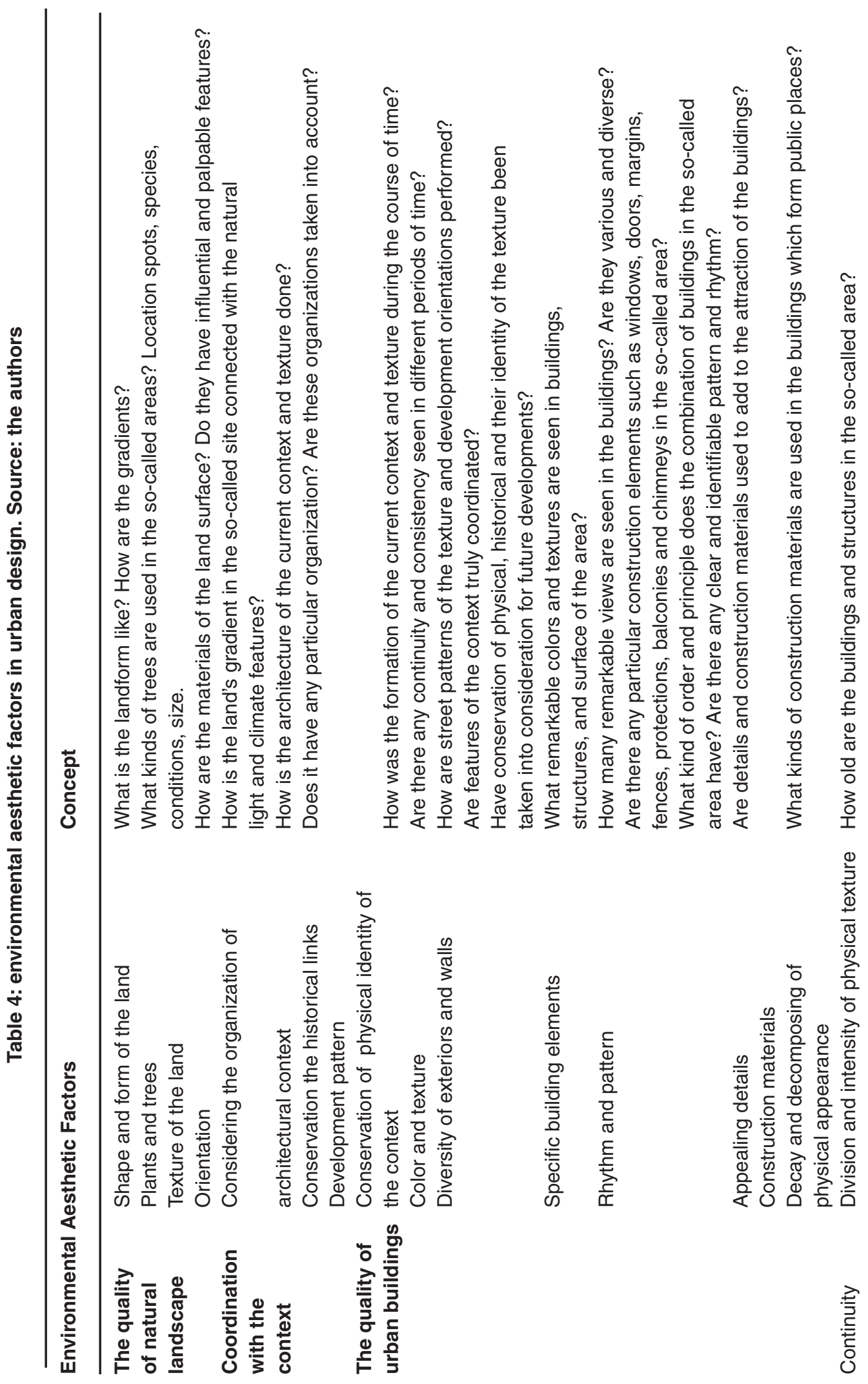




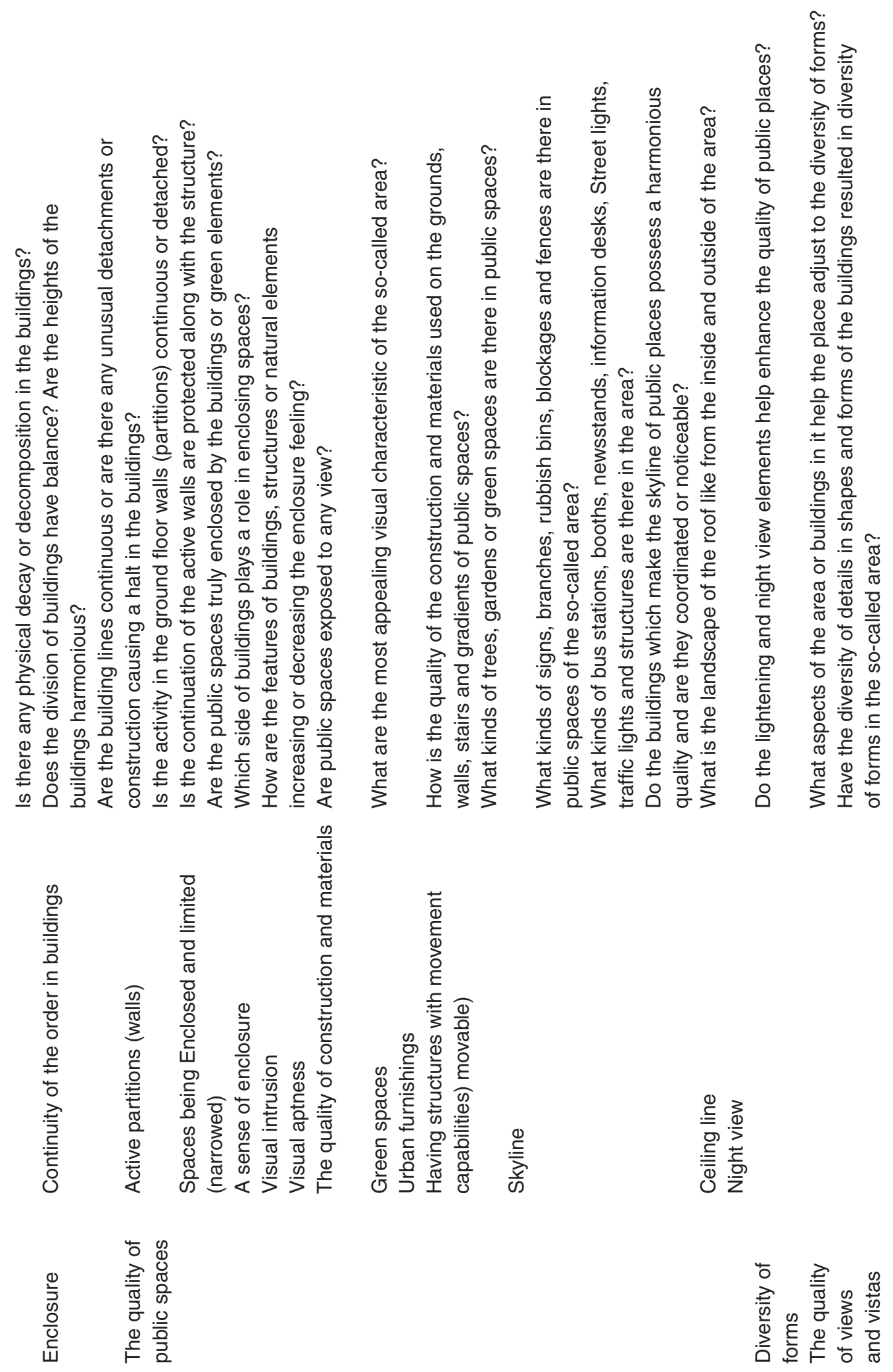



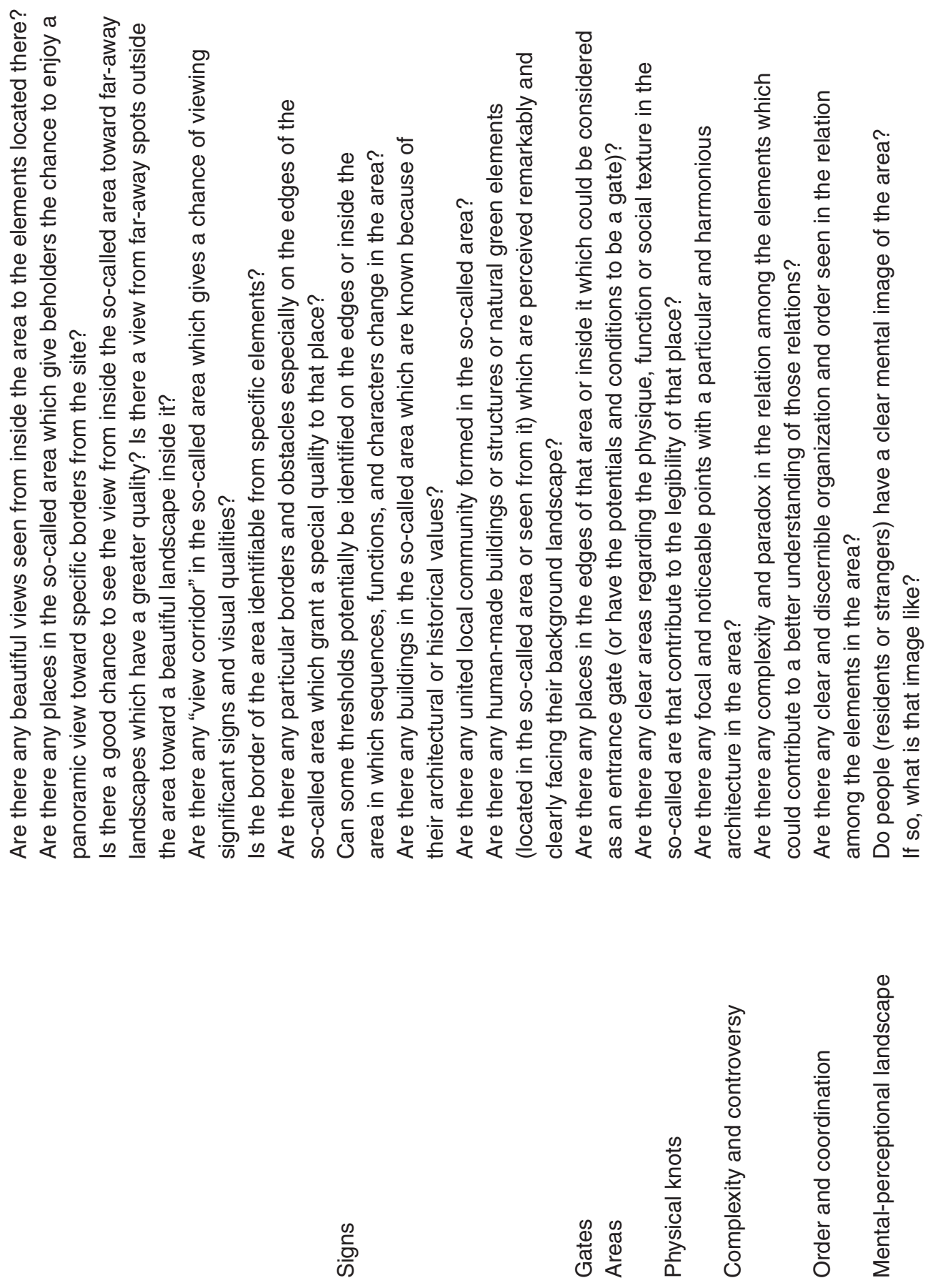


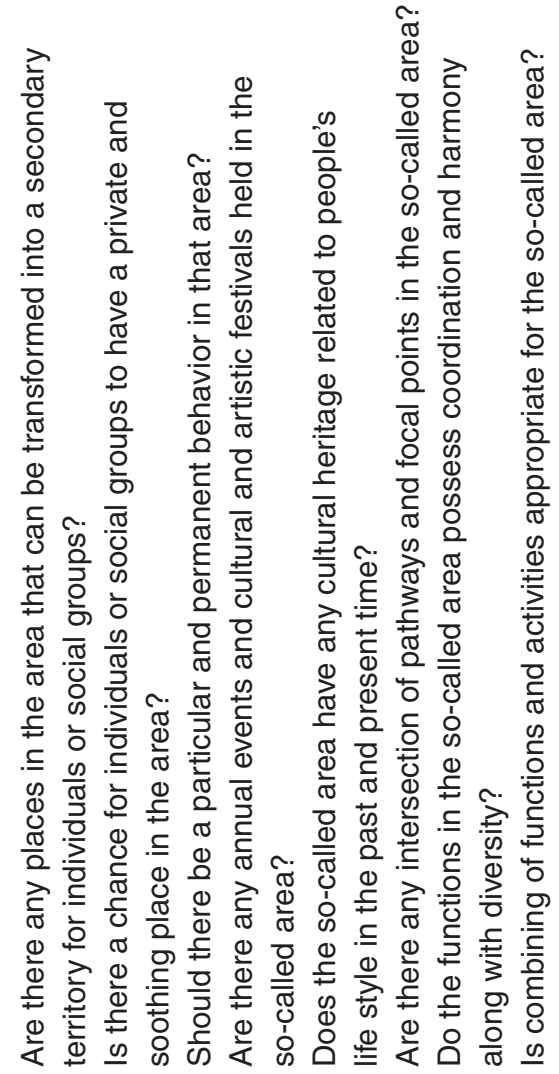

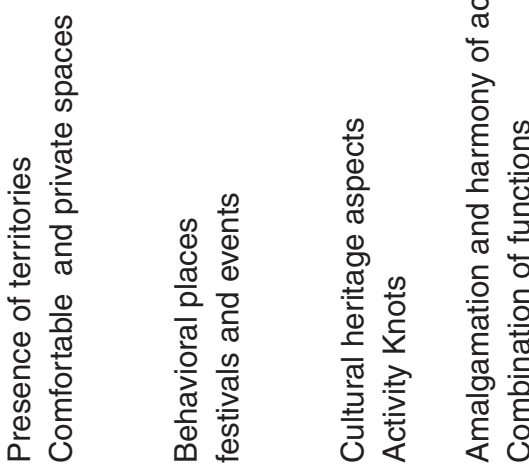

these cities' form. In table 2, the main structure of some important cities and the role of environmental aesthetics in their formation are explained. To explain these characteristics, mostly visual-form factors are taken into account since they provide the context for the formation of cognitive-conceptual factors.

In addition, in table 3, through a comparative study of the main structure of the cities discussed above and based on the suggested factors, the aesthetic-visual evaluation factors of the structures have been explainedthoroughly. (Table 3)

Regarding table 3, it seems that most of the suggested environmental aesthetic factors are appropriate for evaluating the main structure of the cities. In addition, apparently, among visual-form aesthetic factors, the quality of views and vistas are of more significance. Moreover, among cognitiveconceptual factors, identity and legibility are very vital to analyze the environmental aesthetic forms of the city, while, it seems that among the cities discussed above, form of the main structure of Paris and Washington have used visual-form quality of the environmental aesthetics more than any other city.

Like-wise, in table 4, the environmental aesthetic factors, namely, visual-form and cognitiveconceptual factors, and the issues related to them have been explained thoroughly. It is hoped that the results of this research could be used in visualaesthetic analysis of mega-cities' form based on the environmental aesthetic factors.

\section{ACKNOWLEDGEMENTS}

The research for this paper was financially supported by "Tehran Urban Planning and Research Center (TUPRC)". The Authors would like to thank them for their support. 


\section{REFERENCES}

1. Gibberd, F., "Town Design", London: Architectural Press, (1955).

2. Halprin, L., "Freeways", New York, Reinhold, (1966)

3. Cullen, G.," Townscape”, NY: Reinhold, (1961).

4. Newman, O., "Defensible space: people and design in the violent city", London, Architectural Press,(1972).

5. Jacobs, J., "The Death and Life of Great American Cities", New York: Random House, (1961).

6. Relph, E. ,'Place and Placelessness", London, pion, (1976).

7. Jakson, J. B., "The necessity for ruins", Amherst;University of Massachusetts Press, (1980).

8. Norberg-Schulz, C., , "Genius Loci: Paysage, Ambiance, Architecture”, Brussels; Mardaga, (1981).

9. Appelton, J., "Prospects and refuges revisited" Landscape Journal 8; 91-103, (1984).

10. Kaplan. S., "Aesthetics, affect, and cognition: environmental preferences from an evolutionary perspective", Environment and Behavior 19, (1987).

11. Zamiran, Mohammad, "Philosophica Thinking in the Turn of the Second Millennium", Hermes Publications, Tehran, (2002) [In Persian]

12. Grutter, Jorgkurt, "Aesthetics in Architecture", Trans: Jahanshah Pakzad, Second edition, Shahid Beheshti University Press, Tehran, (2005) [In Persian]
13. Jencks, Ch., "What Is Post-Modernism?", NY, St. Martin's Press, (1986).

14. Bell, S., "Landscape: Pattern, Perception, and Process", London, E \& FN Spon Press, (1999).

15. Lynch, K.,"The image of the city". Mass, MIT Press, (1960).

16. Lynch, K.,"Good city form “, Mass, MIT Press, (1984).

17. Boyer, Ch., "The city of collective memory",MIT press, USA, (1994).

18. Bacon, E., "Design of Cities", NY, Penguin Books, (1976).

19. Bentley, I; Alcock, A.; McGlynn, S; Murrain, P. Smith, G., Responsive environments: A manual for designers. Oxford, Butterworth Architecture, (1992).

20. Carmona, M. et al., Public spaces - Urban places: The dimensions of urban design. Architecture Press, (2003).

21. Encyclopedia of aesthetics, Editor in chief: Michael Kelly, vol (2), entry of formalism, pp 213-225, oxford, (1988).

22. Kaplan. R. and Kaplan. S., "The Experience ofNature: A Psychological Perspective", CambridgeUniversity. Cambridge,UK, (1991).

23. Porteous, J.D., Environmental Aesthetics: Ideas, Politics and Planning, London, Routledge, (1996).

24. Nasar, J., "Urban Design Aesthetics- The Evaluative Qualities of Building Exteriors", Environment and Behavior, 26(3): 377-401, (1994). 